\title{
VLOGA VOJSK V EVROPI: OD OBRAMBE OZEMLJA \\ K RAZNOVRSTNIM VARNOSTNIM NALOGAM
}

\section{THE ROLE OF ARMED FORCES IN EUROPE: FROM TERRITORIAL DEFENCE TO VARIOUS SECURITY TASKS}

Povzetek Spreminjanje vloge vojsk v evropskih državah pod vplivom dogajanj po hladni vojni postavlja številna vprašanja tako na teoretični kot na praktični ravni. Na spremembo vloge vojsk pomembno vplivajo predvsem ozemeljska (pre)razporeditev konfrontacij in konfliktov, spreminjanje podobe oboroženih konfliktov ter povečanje pripravljenosti zahodnih držav za vojaško posredovanje v soseščini. Prispevek obravnava teoretična razmišljanja o vlogi vojsk v evropskih državah, prikaže pa tudi nekatere analitične poglede na vlogo vojsk v okviru Nata in EU. Najbolj pomembna sprememba glede vloge vojsk je zmanjševanje potrebe po obrambi ozemlja ter pojav precej različnih in pogosto nejasno definiranih nalog. Tem spremembam pa morajo države prilagoditi tudi obrambne doktrine ter strukturo vojsk. Postopno slovo od ozemeljske obrambne vloge vojske za oblikovalce obrambne politike odpira vrsto vprašanj tako glede odnosa med vojsko in njenim družbenim okoljem kot tudi glede njene notranje organiziranosti.

Ključne besede

Abstract

\section{Vojska, obramba ozemlja, Nato, Evropska unija, mednarodna varnost.}

The changing roles of armed forces in European countries, which are influenced by the post- Cold War developments, have opened many questions both, on the theoretical and practical level. The role of the armed forces is influenced mostly by: the territorial (re)location of confrontations and conflicts, the changing feature of armed conflicts and increased willingness of Western states to intervene in their neighbourhood. The article discusses theoretical considerations on the role of armed forces in European countries and presents also some analytical views on the role of armed forces military roles in the framework of NATO and EU. The most important change concerning the role of armed forces is a diminishing need for territorial defence and the emergence of different and frequently vaguely defined tasks of European states' armed forces. These changes require also the adaptation of defence 
doctrines and military structure. A gradual farewell to the territorial defence function of the armed forces raises numerous questions for defence policy-makers, which concern the relations between the armed forces and their social environment as well as the military internal organisational structure.

Key words Military, territorial defence, NATO, European Union, international security.

Uvod Vojska je institucija, ki jo države uporabljajo kot instrument zagotavljanja varnosti in obstoja. Vendar takoj, ko prestopimo prag tega najbolj splošnega razumevanja vojske, naletimo na dejstvo, da se njene vloge v različnih okoljih in zgodovinskih okoliščinah razlikujejo. V obdobju od začetka devetdesetih let prejšnjega stoletja smo priča korenitim spremembam varnostnega okolja zaradi konca hladne vojne in drugih sprememb v sodobni družbi, ki so pogosto povezane s procesom globalizacije. Pri spremembah vloge vojske ne gre za neproblematično prilagajanje drugačnemu okolju. Pojavljajo se številna vprašanja, povezana z razumevanjem nalog vojske, njene vloge v družbi, najbolj ustrezne organiziranosti glede na potrebe, ki jih postavlja prihodnost ipd. Eno ključnih vprašanj se nanaša na pomen vojske kot varuha ozemeljske celovitosti države. V prispevku so prikazane ključne ugotovitve raziskovalcev o spremembah vloge vojske v evropskih državah, ${ }^{1}$ te pa dopolnimo še s prikazom razmišljanj o vlogi vojsk v okviru Nata in EU.

Spremenjeno varnostno okolje je večini evropskih držav prineslo znatno zmanjšanje jasno določenih vojaških groženj, hkrati pa tudi vrsto negotovosti, zaradi katerih vojske ostajajo pomemben varnostni instrument države. Ta položaj pa spremljajo precej nejasne predstave o namenu in uporabnosti vojsk. Uveljavljene predstave o vojski, ki je predvsem varuh ozemeljske celovitosti države, so vse manj ustrezna podlaga za razumevanje vojske in tudi za njeno organiziranje ter usposabljanje. Vojske evropskih držav se bodo v prihodnje srečevale z nizom zelo raznovrstnih nalog, ki jih bodo opravljale $\mathrm{v}$ večnacionalnem in multikulturnem okolju in $\mathrm{v}$ razmerah, ki bodo bistveno drugačne od vojn, kot jih poznamo iz preteklosti.

\section{TEORETIČNI PRISTOPI K RAZUMEVANJU VLOGE VOJSKE}

Sodobni znanstveni pristopi se proučevanja vojske in njene vloge lotevajo z različnih strani. Pogosto se problematike vojske lotevajo znanstvene discipline, ki proučujejo mednarodno politiko, diplomacijo, varnost ter vojne in konflikte. Temu politološko naravnanemu pristopu je treba dodati še sociološki pristop obravnave. Sociološki pogledi, ki so se razvijali od druge svetovne vojne naprej, obravnavajo vojsko kot družbeno institucijo, proučujejo njene značilnosti ter funkcije in položaj v družbi.

\footnotetext{
Problematika, ki je obravnavana v prispevku, se nanaša na evropske članice Nata in/ali na članice EU. Sicer v literaturi zasledimo različno in pogosto nejasno rabo oznake »evropski«. Nekateri avtorji z njo označujejo EU, pri ameriških avtorjih pa se raba te oznake večkrat nanaša na evropske članice Nata.
} 
Politološki pristopi vojsko praviloma obravnavajo $\mathrm{v}$ kontekstu proučevanja mednarodne politike in $\mathrm{v}$ vlogi instrumenta države kot akterja $\mathrm{v}$ mednarodnih odnosih. Vojska je eden izmed instrumentov moči države, ki ga ta v kombinaciji z drugimi instrumenti moči ${ }^{2}$ lahko uporablja za doseganje svojih ciljev. Vojaška sila je s pravnimi normami opredeljen instrument nasilja, ki ga države uporabljajo $\mathrm{v}$ medsebojnih odnosih in če je treba tudi pri zagotavljanju notranje varnosti, poleg tega pa je lahko tudi manj povezana s temi nalogami, na primer s svojo simbolno vlogo pri graditvi in ohranjanju državnosti (Garnett, 1987, str. 71). Realistični pristop k mednarodni politiki razume vojaško silo predvsem kot instrument, ki zagotavlja suverenost države $\mathrm{v}$ anarhičnih mednarodnih razmerah oziroma zagotavlja preživetje države ob objektivnih zunanjih grožnjah. Vendar pa ta varnostna funkcija v sodobnosti ne obsega samo ozko razumljeno obrambo ozemlja države, temveč tudi obrambo vrednot, ekonomskega blagostanja ter človekovo in okoljsko varnost (Forster, 2006, str. 76). Gre torej za različne cilje ali referenčne objekte, ki jih država s pomočjo vojske varuje.

V teoretičnem proučevanju najdemo tudi poskuse bolj natančnih opredelitev funkcij vojaške sile oziroma razčlenitve načinov in namenov, za katere jo države lahko uporabljajo. ${ }^{3}$ Robert Art (1992) opredeli štiri temeljne funkcije vojaške sile: 1. obramba, ki vključuje tudi preventivno uporabo sile; 2. odvračanje potencialnega nasprotnika; 3. prisiljevanje, s katerim vplivamo na ravnanje nasprotnika; 4. razkazovanje sile, ki je usmerjeno predvsem v doseganje spoštovanja in prestiža in je lahko namenjeno domači ali mednarodni javnosti. Art opozarja, da je v mnogih primerih, kot je na primer odvračanje, prisiljevanje in seveda tudi razkazovanje sile, mogoče z vojaško silo doseči zastavljene cilje, ne da bi jo tudi fizično uporabili. Opozori, da pravzaprav zelo malo držav lahko vojaško silo uporablja v celotnem spektru naštetih funkcij.

V predstavljeni teoretični okvir obravnave vloge vojske je treba dodati še njeno razumevanje v okviru delovanja mednarodnih struktur: organizacij, zavezništev, koalicij. Čeprav organiziranje in upravljanje vojaških sil ostaja v domeni nacionalnih držav, pa imajo te strukture pomemben vpliv na določanje nalog ter organizacijo in usposabljanje sil. V tem kontekstu Forster (2006, str. 137-167) obravnava vpliv EU in Nata na obrambno sodelovanje med državami in na strukturo ter reforme oboroženih sil. Opozori na konstitutivne norme, ki nastajajo znotraj teh organizacij in s katerimi države članice (pre)oblikujejo svojo identiteto, in na regulativne norme, ki opredeljujejo standarde organiziranja in uporabe vojaške sile.

Sociološki pristopi vojsko obravnavajo predvsem kot eno od družbenih institucij ter $\mathrm{z}$ vidika specifične vloge $\mathrm{v}$ družbi. Uporaben okvir glede proučevanja njenih značilnosti in specifičnosti podajajo Soeters, Fenema in Beeres (2010), ki vojaško

\footnotetext{
Tradicionalni pristop k instrumentom nacionalne moči razlikuje med vojaško, ekonomsko in diplomatsko močjo. $V$ sodobnosti pa pogosto $k$ tej moči dodajajo še informacijsko moč. Za poglobljeno razpravo o instrumentih nacionalne moči glej Kotnik, 2012.

3 Navedeni teoretični pristopi obravnavajo vojsko oziroma vojaško silo, s katero razpolaga država. Pri tem ne smemo pozabiti, da imajo lahko vojaško silo na voljo tudi različni nedržavni akterji.
} 
organizacijo opredelijo s temi značilnostmi: 1. umeščenost $\mathrm{v}$ področje politike $-\mathrm{v}$ sodobnih demokracijah je vojska izvršna sila na področju nacionalne in mednarodne varnosti ter javnega reda in je glede nalog in vloge odvisna od politične oblasti; 2 . trajnost ter pomanjkanje jasno definiranih ciljev - vojaška organizacija, podobno kot druge vladne institucije, ima zagotovljen obstoj, ni odvisna od tržnih zakonitosti ponudbe in povpraševanja in zagotavlja kolektivno dobro (colective good), naloge pa so pogosto zelo nejasno definirane in tudi težko merljive z vidika učinkovitosti; 3 . raznolikost nalog (multitasking), multinacionalnost in partnerstvo - sodobne vojske pogosto v multinacionalnem okolju ter v sodelovanju s civilnimi partnerji opravljajo vse bolj raznovrstne naloge; 4. birokratiziranost - jasna delitev dela in poveljniških pristojnosti, dosledna organizacijska pravila pa tudi rigidnost in omejen pretok informacij; 5. prisotnost nasilja in strahu - vojska razpolaga s pooblastili za uporabo nasilja, pri čemer sta pomembni nadzorovana uporaba sile in legitimnost, pri tem se srečuje tudi s pojavom strahu in panike med pripadniki, kar poskuša omejevati na različne načine, najpomembnejša sta urjenje in dril.

Sociološke obravnave se osredotočajo na proučevanje družbene funkcije vojske ter njenega razmerja do države. $Z$ vidika problematike, ki jo obravnavamo v prispevku, so uporabni predvsem pristopi, ki so osredotočeni na mnogovrstnost njenih funkcij ter na proces njihovega spreminjanja v prostorskem in časovnem okvirju. Forster (2006, str. 76-79) se proučevanja te problematike loteva na podlagi klasifikacije funkcij vojske v odnosu do lastne države. Razločevanje je le analitično, predstavljene funkcije so nekoliko povezane ali pa se tudi prekrivajo. ${ }^{4}$ Razločuje pet osnovnih funkcij vojske:

- zagotavljanje nacionalne varnosti (national security): je obravnavano kot njena primarna funkcija in obsega različne naloge. V sodobnosti, hkrati s širitvijo razumevanja varnosti, te naloge obsegajo tudi obrambo vrednot, blagostanja, človekovih svoboščin, vključevanje v mednarodne humanitarne in druge misije vključno s preventivnimi intervencijami zunaj ozemlja države. Forster tudi opozori, da o tem, kaj so specifične naloge vojske, odločajo vlade, ki pri tem izhajajo iz presoje groženj, ki pa niso samo objektivno dejstvo, temveč so odvisne tudi od tega, kako jih dojemamo: diskurz o (ne) varnosti ni »dan«, pač pa družbeno in politično konstruiran okoli identitet, interesov in pomenov »nas « in »njih« (prav tam, str. 77);

- graditev državnosti (nation building): ta vloga vojske je po eni strani tesno povezana z njegovo vlogo v zagotavljanju nacionalne varnosti, saj sta obramba pred grožnjami in percepcija nacionalnega interesa in vrednot tesno povezana. Posebno funkcijo v okviru te vloge ima tam, kjer je vojaška obveznost, ki pogosto služi tudi kot način širjenja družbenih in političnih (nacionalnih) vrednot, promociji občutka nacionalne enotnosti itn.;

\footnotetext{
Kot opozarja Bergman, ki ga navaja Forster (2006, str. 80), lahko uporaba vojske v operaciji vzpostavljanja miru za državo pomeni doseganje nacionalnovarnostnega cilja obrambe države, lahko pa je hkrati tudi motivirana z doseganjem zunanjepolitičnih ciljev in vrednot, kar je tipična vsebina vojaške diplomacije.
} 
- obramba režima (regime defence): vojska lahko podpira partikularne politične interese režima, lahko pa tudi stranke ali posameznika. Pogosto je v takšni vlogi vojska v avtokratskih režimih, lahko pa tudi v liberalnih demokracijah;

- pomoč domačim oblastem (domestic military assitance): na splošno obsega različne aktivnosti, od pomoči $\mathrm{v}$ primeru zagotavljanja zakonitosti, reda in javne varnosti, pomoči javnim službam pa do pomoči ob katastrofah in naravnih nesrečah;

- vojaška diplomacija (military diplomacy): obsega »neoperativno uporabo« vojske za doseganje ciljev zunanje in obrambne politike. To so lahko različne aktivnosti, kot na primer bilateralna ali multilateralna urjenja in izmenjava, pomoč pri izvajanju vojaških reform ali obrambne konverzije, vojaški ukrepi za graditev zaupanja ter pomoč drugim državam pri izvajanju reform varnostnega sektorja.

Kratka predstavitev nekaterih najbolj razširjenih teoretičnih pristopov k vlogi vojske je namenjena pomoči pri razumevanju njene vloge v mednarodnih odnosih in družbi. $\mathrm{Na}$ najbolj splošni ravni lahko omogočajo teoretično oporo za razumevanje vloge vojske v evropskem kontekstu, pri čemer pa je treba upoštevati njegove posebnosti. Lahko so kot analitično »orodje« za proučevanje vloge vojske v konkretnem družbenem okolju.

\section{EVROPSKA VARNOSTNA PARADIGMA PO KONCU HLADNE VOJNE IN VLOGA VOJSK}

Predstavljeni teoretični okvir nas opozori, da so naloge vojske raznovrstne. Spremembe razmer v mednarodnem okolju, lahko pa tudi družbene spremembe v državah, se odražajo tudi v spremembah funkcij vojske. Ključne za razumevanje sedanjih razprav o vlogi vojsk so spremembe, ki so nastale s koncem hladne vojne. Odprava konfrontacije med Vzhodom in Zahodom je pomenila tudi konec priprav za vojno med znanimi nasprotniki ter po vnaprej predvidenih scenarijih. Za evropske države se začnejo postavljati vprašanja o namenu in kakšne naj bodo njihove oborožene sile v prihodnje. Iskanje odgovorov je še posebno zahtevno zaradi nepredvidljivega varnostnega okolja in nejasnosti glede tega, kakšni bodo prihodnji konflikti. Negotovosti, povezane s prihodnostjo, kažejo že dvomi o tem, kako je konec hladne vojne vplival na varnost in stabilnost. Ni jasno, ali je upravičena teza o »medvojnem obdobju«, ki jo obravnava Collinn Gray, glede na katero so devetdeseta, kot obdobje v katerem ni bilo velikih strateških konfrontacij, le »premor« med starim in novim obdobjem konfliktov velesil (Gray, 2012, str. 245-6). Ali lahko govorimo o trajnejših spremembah? Avtor priznava, da je kljub koristnosti navedena teza kontroverzna. Obravnavati jo je mogoče na tri načine: 1. v povezavi z možnostjo nastanka ponovnega konflikta med velesilami; 2. kot nastajanje novega strateškega konteksta, v katerem je vojskovanje med državami odpravljeno; 3. kot obdobje, v katerem asimetrične, predvsem religiozno motivirane grožnje, kot so terorizem ter vstaje in nemiri, postajajo središče globalnega konflikta in glavna grožnja stabilnemu mednarodnemu redu. 
Pogosto poskušajo znanstvene razprave sodobno varnostno okolje razlagati tudi $\mathrm{v}$ povezavi s procesom globalizacije. Ta prinaša nove oblike groženj in tveganj, ki zahtevajo drugačne odgovore v iskanju varnosti. Grizold in Bučar (2011, str. 833) menita, da koristi globalizacije niso za vse družbe enake in da se zdi, da se prepad med razvitimi in nerazvitimi poglablja. Globalizacija kot naraščanje medsebojne odvisnosti povečuje tudi negativne pojave, kot so organiziran kriminal, ekonomske migracije, terorizem, nalezljive bolezni idr. Opozarjata, da »Ponekod notranji družbenopolitični procesi, ki so tudi posledica globalizacijskih procesov, tako destabilizirajo določene družbe, da povzročijo notranje, celo oborožene spopade. To med drugim povzroča, da imamo na eni strani vse bolj povezan svet, ki v ekonomskem, političnem in kulturnem pogledu razpada na vse manjše entitete in identitete.«

Vse navedeno opozarja, da je uporabnost nekdanjih konceptov razumevanja varnosti in s tem tudi vloge vojske omejena in da je nujno iskati nove odgovore v razumevanju sedanje varnostne paradigme. $Z$ vidika razumevanja vloge vojaške sile po koncu hladne vojne $\mathrm{z}$ evropske perspektive so po našem mnenju pomembni trije dejavniki: 1. ozemeljska (pre)razporeditev konfrontacij in konfliktov; 2. spremenjena podoba oboroženih konfliktov; 3. povečanje pripravljenosti zahodnih držav za vojaško posredovanje v svoji soseščini.

1. Konec hladne vojne je pomenil odpravo konfrontacije in pričakovane vojne na evropskih tleh. Tudi sicer se v sodobnosti zmanjšujejo možnosti držav za unilateralno uporabo sile druga proti drugi tako zaradi destruktivnosti sodobnih orožij kot zaradi razvoja mednarodnih norm (Kaldor, 2006, str. 5). Dejanski in potencialni oboroženi konflikti nastajajo na evropskem obrobju in $\mathrm{v}$ bolj oddaljenih delih sveta ter izgubljajo svoj meddržavni značaj. Območje držav EU in Nata predstavlja območje stabilnosti, v katerem ni pričakovati vojn. EU danes pogosto obravnavajo kot jedro območja, v katerem vojaška strateška vprašanja $\mathrm{v}$ odnosih med državami $\mathrm{v}$ resnici nimajo pomena. $\mathrm{V}$ tem območju gre za »kulturno zavrnitev vojne«, ki je posledica posebnih zgodovinskih okoliščin; »post-vojaška EU« predstavlja otok razvoja sredi siceršnjega nereda in nepredvidljivega okolja ter neenakosti na globalni ravni (Gray, 2012, 342). Na podoben način evropsko okolje razume Forster (2006, str. 137-9 in 148), ki se za razlago opira na Deutschev koncept »varnostne skupnosti«, znotraj katere so pričakovanja vojne minimalna. EU in Nato se lahko razume kot jedro skupnosti, ki oblikuje nove vzorce odnosov med državami, in znotraj katere obstajajo praksa miroljubnega reševanja konfliktov ter pričakovanja in nagnjenja k miroljubnim spremembam. V okviru tega kompleksa gre tudi za razvoj konsenza, vojaške in politične transparentnosti in multilateralizma. ${ }^{5}$

\footnotetext{
Podporo tezi o miroljubnosti odnosov med evropskimi državami lahko najdemo tudi v drugih teoretičnih razlagah; npr. v konceptu »kompleksne medsebojne odvisnosti«, ki ponuja razlago, da med industrijsko razvitimi in demokratičnimi državami, ki so medsebojno tesno povezane, verjetnost vojn dejansko ne obstaja (Keohane in Nye, 1989, str. 23-36).
} 
Ob tem pa je za Evropo pomembno, da je bil pojav nasilnih konfliktov na njenem obrobju v devetdesetih zelo intenziven in da se danes srečuje z nestabilnostmi v soseščini in tudi v bolj globalnih okvirih. Devetdeseta leta so prinesla tudi »novi svetovni nered«, v katerem se je »nasilje razmahnilo v velikem delu nekdanje Jugoslavije, v nekaterih delih ruske 'bližnje soseščine' in v nekaterih regijah znotraj Rusije ter v Afriki« (Gray, 2012, str. 338). Danes največjo verjetnost nastanka kriz in oboroženih konfliktov, predvsem notranjih, predstavljajo območja v tako imenovanem »pasu nestabilnosti«, ki se razprostira od Podsaharske Afrike čez Severno Afriko, Bližnji vzhod in Balkan skozi Kavkaz proti južni in osrednji Aziji in delu Jugovzhodne Azije. Največja verjetnost nastanka konfliktov je na območju, ki obsega Severno Afriko, Bližnji Vzhod in se širi proti vzhodu do Pakistana. ${ }^{6}$ Obstajajo možnosti nastanka političnih nemirov, ekstremizma in različnih oblik organiziranega kriminala, na območju je tudi nekaj držav s krhko stabilnostjo (Global Trends 2025, 2008, str. 60, in Strategic Monitor, 2012, str. 10).

2. Druga pomembna sprememba, ki vsaj deloma sovpada s koncem hladne vojne, je celovito spreminjanje podobe vojne. Eden od vidikov teh sprememb je porast števila notranjih konfliktov v primerjavi z meddržavnimi. Podoba vojne, kot jo na splošno poznamo iz zgodovine, kot napad države na drugo državo s težnjo zavzeti ozemlje, zrušiti oblast itn. v sodobnosti izginja. Meddržavno konfrontacijo in oborožen konflikt, ki ga vodijo vojske držav, večinoma nadomestijo grožnje, ki so, gledano z zornega kota zahodnih držav, »asimetrične « narave. ${ }^{7}$ Svete, Guštin in Prebilič (2010, str. 252) opozarjajo na značilnost sodobnih konfliktov, da nasilje pravzaprav omogočajo šibke zmogljivosti držav, kar pomeni izgubo monopola države nad silo in posledično oboroževanje ter organiziranje posameznih skupin. Konflikti postajajo zelo kompleksni in tudi $\mathrm{v}$ prihodnje ni pričakovati veliko konfliktov, pri katerih bi bile vloge sprtih strani jasne in definirane na tradicionalen način, značilen za obdobje hladne vojne.

Oboroženi konflikti, tam kjer do njih prihaja, se glede poteka, ciljev in akterjev razlikujejo od tradicionalno pojmovane vojne. Temeljne spremembe v vodenju vojn tega obdobja raziskovalka Mary Kaldor opisuje s paradigmo »stare« in »nove« vojne. Tako imenovane »stare« vojne so spopadi med državami, ki jih izvajajo redne oborožene sile industrijske dobe, »nove« vojne pa nastajajo $\mathrm{v}$ kontekstu erozije avtonomije države ali njene dezintegracije in v kontekstu erozije monopola legitimnega organiziranega nasilja. Monopol države nad nasiljem je ogrožen »od zgoraj« - s procesom transnacionalizacije oboroženih sil - in »od spodaj« s procesom njihove privatizacije, ki se kaže v nastanku

\footnotetext{
V anglo-ameriški literaturi to območje imenujejo »Razširjeni srednji vzhod« (Greater Middle East).

»Asimetričnost vojne« opredeljuje dejstvo, da »oborožene sile ne bodo več soočene s konvencionalnimi armadami, ki bi se jim odkrito zoperstavile, ampak z demonstranti, gverilci, teroristi, atentatorji, ... ter s pregonom vojnih zločincev, spopadi med različnimi etničnimi, religijskimi ali drugimi skupinami in elitami ipd." (Žabkar, 2005, str. 132). Pojem asimetrije obravnavajo tudi Svete, Guštin in Prebilič (2010), ki opozarjajo, da se ta ne nanaša le na merljive in materialistične indikatorje moči, temveč tudi na neprimerljivost sodelujočih $v$ konfliktih, ki se kaže pri uporabi sredstev in metod.
} 
različnih oboroženih skupin, kot so paravojaške enote, strukture pod vodstvom lokalnih vojaških poveljnikov, kriminalne skupine, skupine najemnikov idr. Cilji »novih« vojn se tičejo identitetne politike, v nasprotju z geopolitičnimi ali ideološkimi cilji vojn v preteklih obdobjih. Identitetna politika vsebuje zahteve po oblasti na podlagi partikularne identitete - nacionalne, klanske, religiozne ali jezikovne. Tudi sredstva, uporabljena v »novih« vojnah, so specifična. Medtem ko je tradicionalno cilj vojne zavzeti ozemlje z vojaškimi sredstvi, je cilj novih vojn nadzor prebivalstva z odstranitvijo vseh, ki imajo drugačno identiteto, in z izvajanjem terorja. Strateški cilj teh vojn je mobilizacija ekstremistične politike, temelječe na strahu in sovraštvu. Nasilje je usmerjeno proti civilistom in vključuje množične izgone s pomočjo ubijanja in drugih načinov političnega, psihološkega in ekonomskega zastraševanja (Kaldor, 2006, str. 5-9).

Oboroženi konflikti so v zadnjih dveh desetletjih dobili povsem drugačno podobo, kot so jo imele vojne moderne industrijske dobe od nastanka nacionalnih držav naprej. Danes se pojmovanje vojne, kot je uveljavljeno na Zahodu, oziroma naša »strateška mentaliteta«, spoprijema s problemom razumevanja vsega, kar ni množični spopad organiziranih oboroženih sil. Naša predstava o vojni, literatura in strateška kultura so še vedno povezani s konvencionalno, regularno vojno med državami (Osinga in Lindley-French, 2010, str. 19).

3. Po hladni vojni smo priča tudi znatnemu povečanju obsega posredovanja zahodnih držav na konfliktnih območjih in v državah, iz katerih bi lahko posredno ali neposredno izhajale grožnje Zahodu. Za Zahod regionalni konflikti, ki jih ustvarjajo etnične ali religiozne skupine, predstavljajo poglavitno varnostno grožnjo. Zahodne vojaške sile so bile od devetdesetih naprej prisiljene v stabilizacijske in protiuporniške operacije na Balkanu, v Afriki, Iraku in Afganistanu (King, 2010, str. 43). Najprej je bilo v devetdesetih zaradi odprave blokade, ki je izvirala iz blokovske delitve, mogoče povečati število mednarodnih mirovnih operacij. V tem obdobju zasledimo rastoči optimizem in povečanje svobode delovanja glede posredovanja mednarodne skupnosti v notranjih konfliktih (Arnold, 2008, str. 191). Tako je samo v obdobju od 1988 do 1993 bilo vzpostavljenih več mirovnih operacij kot od konca druge svetovne vojne do 1987 (Forster, 2006, str. 196). Sredi devetdesetih Nato in nekaj pozneje še EU začneta izvajati prve operacije pod svojim okriljem. K razvoju strategije posredovanja je dodatno prispeval odziv Zahoda na teroristične napade leta 2001. Po teh dogodkih so vojske zahodnih držav vključene v posredovanja, ki jih nekateri označujejo kot »nov tip preventivnih (pre-emptive) posredovanj (Forster, 2006, str. 8). Posredovanjem v Afganistanu (2001) in Iraku (2003), v katerih so bile v prvi fazi ključni akter ZDA, je sledila dolgotrajna prisotnost vojaških sil, v katere so bile vključene vojske številnih evropskih držav. Leta 2003 je imelo 27 držav članic EU skupaj v različnih operacijah v tujini nameščenih 70.281 vojakov. To število se je postopoma zmanjševalo, vendar je do leta 2008 še vedno presegalo številko 60.000, leta 2011 pa ima ta skupina držav še vedno v operacijah v tujini 48.992 vojakov (Geigerich in Nicoll, 2012, str. 59). 
Danes na verjetnost posredovanja vpliva tudi širši sklop družbenih in tehnoloških dejavnikov, kot na primer destabilizacija določenih držav ali območij, možnost, da države in tudi nedržavni akterji uporabijo zelo uničevalne vojaške tehnologije idr. Kot opozarja Arnold (2008, str. 191-2), se z globalizacijo povečuje medsebojna odvisnost držav in celo najmočnejše države so bolj ranljive kot v preteklosti. Širitev vojaške tehnologije, posebno na področju orožij za množično uničevanje in balističnih raket, je povečala pripravljenost mednarodne skupnosti za izvajanje prepovedi teh sredstev in za preventivno delovanje proti »malopridnim« državam. Razvoj mednarodnih norm, predvsem na humanitarnem področju, pa je lahko še dodatna spodbuda za posredovanje ob grobi kršitvi človekovih pravic.

Osinga in Lindley-French (2010, str. 17-8) ugotavljata, da sedanjost označuje »nova strateška kompleksnost«, v kateri je pomemben dejavnik opora zahodne varnostne politike na proaktivno strategijo zmanjševanja tveganja z vojaškim angažiranjem na območjih, kjer gre za padle države in za širitev posledic državljanskih vojn in drugih notranjih konfliktov. Za sedanje obdobje so V spoprijemanju s tveganji značilni »previdnostni pristop« (precautionary approach) in strateška posredovanja. Takšna posredovanja pa so malo ali samo neposredno povezana z izvajanjem samoobrambe (Forster, 2006, str. 196).

\section{SPREMINJANJE VLOGE VOJSKE V TEORETIČNI PERSPEKTIVI}

Z vplivom zgoraj navedenih sprememb na vlogo vojske se v zadnjih dveh desetletjih ukvarjajo skoraj vsi pomembni raziskovalci vojske na Zahodu. Znanstvene razprave opozarjajo na spremembe, ki so posledica razmer $\mathrm{v}$ mednarodnem okolju in $\mathrm{v}$ številnih državah tudi notranjih družbenih sprememb. V evropskem kontekstu je najbolj splošna sprememba zmanjšanje pomena zunanje obrambne funkcije vojske in predvsem pomena obrambe ozemlja, ob hkratni preusmeritvi na nove naloge (Edmunds, 2005, str. 9; Moskos, 2005; Forster, 2006, str. 2; Malešič, 2005, str. 1). Spreminjanje prednostnih nalog v vojski je zahtevalo tudi predrugačenje obrambnih doktrin, strukture vojske, opreme, načel delovanja in usposabljanja.

Kot ugotavlja Moskos (2005, str. 20-1), je bila za tradicionalno vojsko temeljna grožnja sovražna invazija, njena temeljna naloga pa je bila obramba domovine. Po koncu hladne vojne so naloge vojske vedno bolj osredotočene na multinacionalne mirovne in stabilizacijske operacije. Značilnost tega obdobja je zmanjševanje pogostosti vojn med državami in porast števila vojn znotraj držav ter terorizma, ki presega državne meje. Meni tudi, da bodo v prihodnje države najbolj verjetno $\mathrm{v}$ vojnah z necentraliziranimi revolucionarnimi gibanji. Moskos z uporabo koncepta "postmodernega vojaštva $«^{8}$ teoretično ilustrira spreminjanje njegove vloge v obdobju po hladni vojni. Koncept, ki sicer odraža predvsem razvoj ameriškega vojaštva, je

\footnotetext{
Omenjeni koncept temelji na razlikovanju tipov vojaške organizacije v različnih obdobjih: moderni tip (obdobje pred hladno vojno 1900-1945), zgodnjemoderni tip (obdobje hladne vojne 1945-1990) in postmoderni tip (obdobje po letu 1990).
} 
precej uporaben tudi za razumevanje vojaštva evropskih držav. »Postmoderni« tip vojaštva označujejo spremembe nalog, odnosa z okoljem ter notranje strukture in značilnosti. Z vidika spreminjanja njegove vloge so ključne naslednje spremembe: namen vojaštva se spreminja od vodenja vojn $\mathrm{k}$ nalogam, ki so za vojaštvo netradicionalne; vojaške sile se uporabljajo v mednarodnih nalogah, ki jih odobrijo ali pa vsaj legitimizirajo naddržavne strukture; vojaške sile se internacionalizirajo z oblikovanjem večnacionalnih struktur. »Postmoderni« koncept vojaštva je povezan s spremembami groženj - v preteklosti sta grožnjo predstavljali predvsem sovražna invazija ter jedrska vojna, v sedanjosti pa grožnje nastajajo na »poddržavni« ravni, kot sta na primer etnično nasilje in terorizem. Skladno s tem se spreminjajo tudi glavne naloge vojaštva - od obrambe domovine in podpore zavezništvu v preteklosti k novim nalogam, kot so mirovne in humanitarne naloge (Moskos, Williams, Segal, 2000, str. 2-17). Predstavljeni model je sicer presplošen, da bi popolnoma ustrezal značilnostim spreminjanja vloge vojaštva $\mathrm{v}$ različnih državah v Evropi, očitno pa odraža splošen trend sprememb na tem področju.

V evropskih državah spreminjanje vloge vojske ne poteka samo v nacionalnem kontekstu, temveč na to vliva tudi skupna politika, ki se oblikuje v okviru EU in Nata. Tudi teoretične razprave o prihodnji vlogi Nata kažejo na spreminjanje prioritet od obrambe ozemlja k posredovanju ob krizah in konfliktih v svetu ter $\mathrm{k}$ spoprijemanju z grožnjami, ki ne pomenijo neposrednega ogrožanja ozemlja članic. Izvirni namen zavezništva je bil vojaška obramba držav članic. Osnovna podmena 5. člena Severnoatlantske pogodbe (SAP) je bila nevarnost hkratnega napada vzhodnega bloka na skupino najbolj strateško izpostavljenih članic zavezništva, vzporedna podmena pa, da bodo napad izpeljale izključno oborožene sile sovražnih držav (Bebler, 2006, str. 28). Kolektivna obramba je bila tradicionalno pojmovana kot zaščita ozemelj zaveznic pred oboroženim napadom (Yost, 2010, str. 489). Preobrazba Nata v zadnjih dveh desetletjih spreminja njegov ozemeljsko obrambni značaj, kar se je jasno odrazilo tudi v njegovem zadnjem strateškem konceptu iz leta $2010 .{ }^{9}$ Flockhart (2011, str. 15-6) v analizi tega dokumenta opozarja na preusmeritev Nata »k bolj globalnemu angažiranju, ker so vse tri ključne naloge zavezništva (vključno s kolektivno obrambo) pridobile globalno in ekspedicijsko razsežnost in ker ni več specifične omembe 'ozemlja' zavezništva ali držav članic ... v novem strateškem konceptu je 'obramba ozemlja' osredotočena na raketno obrambo.« Ugotavlja, da kljub ohranjanju veljavnosti 5. člena SAP sedanji Natov strateški koncept dokazuje, da Nato ni več preprosto »obrambno zavezništvo«, temveč varnostna institucija, ki je regionalno umeščena, vendar se zaveda, da je varnost v 21. stoletju globalna.

Spremembo povezanosti določil 5. člena SAP in obrambe ozemlja nekateri avtorji obravnavajo kot »deteritorializacijo« kolektivne obrambe. Pri tem Natov statični, na odzivu temelječ in ozemeljski koncept kolektivne obrambe zamenjuje funkcionalni pristop (Yost, 2010, str. 505-7; Zapolskis, 2010, str. 46). Prelom z uveljavljeno vlogo Nata v obrambi ozemlja članic se v praksi pa tudi v strateških dokumentih

Celovita analiza Strateškega koncepta Nata 2010 je bila predstavljena v članku Aljaža Fabjana, objavljenem v reviji Sodobni vojaški izzivi, december 2012. 
izrazito odraža z usmeritvijo v krizni menedžment. Težišče delovanja zavezništva so v zadnjih dveh desetletjih predstavljale operacije, predvsem tiste bolj dolgotrajne, ki jih je izvajalo na Balkanu in v Afganistanu. Ozemeljski vidiki, ki so skozi 6. člen SAP vgrajeni v koncept kolektivne obrambe, bodo v prihodnje vse manj pomembna podlaga za njeno izvajanje. Uporabo koncepta kolektivne obrambe bodo lahko zahtevale različne grožnje, ki niso neposredno usmerjene na ozemlje zaveznic. ${ }^{10}$ Zaveznice se danes srečujejo z vprašanji, ali je mogoče določilo o kolektivni obrambi uporabiti tudi v primeru drugih groženj, kot so kibernetski napad, napad z orožji za množično uničevanje, zaznana nevarnost terorističnega napada ali prekinitev poti za preskrbo z energetskimi viri (Zapolskis, 2010, str. 32; NATO 2020, 2010, str. 14-5). $\mathrm{V}$ prihodnje bo razumevanje kolektivne obrambe (uporaba 5. člena SAP) verjetno vse manj povezano z neposrednimi grožnjami ozemlju zaveznic.

Vse navedene spremembe odpirajo številna vprašanja o razumevanju vloge vojske, ki je bilo uveljavljeno v zadnjih nekaj stoletjih. Predrugačenje varnostnega okolja ne pomeni, da se tradicionalno razumevanje vojske kot jamstva ozemeljske celovitosti države v celoti umika iz razumevanja varnosti. »Obramba nacionalnega ozemlja ostaja čvrsto ukoreninjena v institucionalni legitimnosti oboroženih sil ... kar otežuje opuščanje ali deprioritiziranje vloge oboroženih sil v obrambi ozemlja« (Edmunds, 2005, str. 10). Vendar pa spremembe, ki so privedle do minimaliziranja verjetnosti ozemeljskih groženj, odpirajo vprašanje, kako naj države svoje varnostne doktrine in vojaške strukture prilagodijo drugim, bolj verjetnim grožnjam varnosti. Grožnje, ki danes pomenijo bolj verjetno ogrožanje interesov ali pa resno oviro delovanja držav, niso primarno grožnje ozemeljski celovitosti. Njihovo odvračanje pa pogosto zahteva uporabo vojske v okviru mednarodnih organizacij ali koalicij zunaj ozemlja države, lahko se pokaže potreba po vnaprejšnjem preventivnem delovanju, ki ni le reakcija na dejanje nasprotnika, pogosto pa je nujna tudi dolgotrajna prisotnost $\mathrm{v}$ nestabilnih območjih.

Spremembe varnostnega okolja zahtevajo prilagoditev strukture in zmogljivosti oboroženih sil. Žabkar (2005, str. 134-5) ugotavlja, da v obdobju globalizacije prevladuje prepričanje, da evropske države v prihodnje ne bodo več potrebovale nekdanjih množičnih oboroženih sil niti množičnih rezervnih enot, ki jih je mogoče ob napetosti mobilizirati. »Namesto tega zadostujejo: 1. manjše število trenutno pripravljenih visokomobilnih zračnodesantnih, pomorskodesantnih, oklepnih in mehaniziranih enot vrhunske kakovosti; 2. močna letalska in satelitska podpora; pomorska in zračnotransportna sredstva za njihov hiter prenos do kriznih območij.«

Z vidika pričujoče razprave pa je najbolj pomemben trend širitev razumevanja vloge vojsk pri zagotavljanju nacionalne varnosti, in sicer od varovanja ozemlja države $\mathrm{k}$ širšemu sklopu nalog, ki vključujejo tudi delovanje v mirovnih stabilizacijskih in

\footnotetext{
${ }^{10}$ V resnici danes kot edino morebitno, čeprav malo verjetno, neposredno grožnjo ozemlju zaveznic obravnavajo omejen poseg Rusije, proti kateri od baltskih držav ali Poljski. Vendar v Natu takšna možnost, predvsem pa možnost obsežnejše vojne, ne vzbuja velike zaskrbljenosti; menijo namreč, da bi takšen scenarij bilo mogoče dovolj zgodaj predvideti in da imajo dovolj zmogljivosti za odgovor (Asmus, 2010, str. 2).
} 
drugih operacijah ob krizi v tujini. Ozemeljska celovitost države v takih primerih praviloma ni ogrožena. Manj jasna in neposredna je tudi povezanost z nacionalno varnostjo države. V širšem smislu je v takih primerih uporaba vojske lahko povezana z zagotavljanjem nacionalne varnosti, vendar je povezava pogosto manj očitna, zato je lahko tudi problematična $\mathrm{z}$ vidika legitimnosti v domači javnosti.

Ob tem, ko je postopno slovo od ozemeljsko obrambne funkcije vojske za evropske države $\mathrm{v}$ zadnjih dveh desetletjih najbolj izrazit proces povezan z vprašanjem njenih nalog, je problematika aktualna tudi z vidika širšega konteksta njene družbene vloge. Raziskovalci opozarjajo, da se spreminjata pomen in položaj vojske v družbi. Edmunds (2005, str. 10) meni, da se je za večino evropskih držav možnost zunanje vojaške grožnje tako zmanjšala, da ne zagotavlja več nespornega razloga za obstoj in delovanje oboroženih sil. Gledano z zornega kota uvodoma predstavljenih funkcij, kot jih obravnava Forster, je mogoče zaznati spremembe pravzaprav pri vsaki od petih funkcij (Forster, 2006, str. 96-7). Glede temeljne funkcije, to je zagotavljanja nacionalne varnosti, je zaslediti trend upadanja pomena vojske kot posledice zmanjševanja groženj ozemeljski celovitosti držav. Vendar je v obdobju po 2001 zaradi zaznave groženj terorizma zaslediti tudi širitev nalog, ki so pogosto tudi ekspedicijske narave. Izvajanje mirovnih nalog prav tako vstopa v okvir razumevanja njene varnostne vloge. Funkcija vojske v graditvi državnosti prav tako v sodobnih evropskih državah postaja manj pomembna, deloma zato, ker se njena socializacijska vloga $\mathrm{z}$ odpravo nabora zmanjšuje, pa tudi sicer pri oblikovanju nacionalnih vrednot $\mathrm{v}$ sodobnosti izgublja svojo vlogo. Vendar o slednjem ni enotnega mnenja in Edmunds (2005, str. 13) meni, da graditev državnosti v evropskih državah ostaja pomembna funkcija vojske, tudi zaradi odsotnosti jasne grožnje. Pomen pa dobiva vloga vojsk na področju pomoči domačim civilnim oblastem, delno zaradi spreminjanja prioritet ob odsotnosti zunanje grožnje in delno zaradi vloge, ki se vojski pripisuje v boju proti terorizmu. Znatno se je okrepila vloga vojske pri izvajanju različnih aktivnosti, ki jih splošno obravnavajo kot vojaško diplomacijo; predvsem gre za različne oblike vojaškega sodelovanja, ki poteka med članicami Nata in EU ali pa med članicami in tretjimi državami. ${ }^{11}$

\section{PRIHODNJA VLOGA VOJSK V OKVIRU NATA IN EU}

Razmišljanja o vlogi vojsk v prihodnosti potekajo tudi v okviru EU in Nata. Pri tem so namen vojaških sil in njihove naloge preveč splošno in nenatančno predeljeni in zdi se, da je več pozornosti namenjene razpravi in politiki glede vojaških zmogljivosti. ${ }^{12}$ Watanabe (2010, str. 62) meni, da je EU konec devetdesetih začela razvoj zmogljivosti brez trdnega dogovora o vrstah nalog, ki naj bi jih v prihodnje izvajala. Geigrich in Nicoll (2012, str. 53-4) ugotavljata, da izkušnje zadnjih 20. let

\footnotetext{
${ }^{I}$ Za te aktivnosti se pogosto uporablja tudi izraz obrambna diplomacija (defence diplomacy), ki pa je vsebinsko nekoliko širši sklop aktivnosti. Vojaška diplomacija predstavlja segment obrambne diplomacije. Za obsežen pregled aktivnosti obrambne diplomacije po hladni vojni glej Cottey in Forster, 2004.

12 V EU prizadevanja za povečanje skupnih vojaških zmogljivosti držav članic potekajo v okviru programa Pooling and Sharing, v Natu pa gre za podobna prizadevanja v okviru pobude, imenovane Smart Defence.
} 
kažejo, da bodo evropske države tudi v prihodnje morale pošiljati vojaške sile v zelo različne operacije z raznovrstnimi nalogami: »Difuzna narava groženj v negotovem svetu prispeva k splošni nejasnosti glede namena obstoja oboroženih sil, dokumenti glede obrambne politike, ki so nastajali v obdobju od konfliktov na Balkanu naprej pa so bolj ko ne podobni seznamu nevarnih problemov in brez resnejših prizadevanj po oblikovanju prioritet.« Menita, da v sedanjih varnostnih razmerah obstaja vrsta negotovosti $\mathrm{v}$ soseščini, vendar ni novih neposrednih in eksistenčnih groženj varnosti evropskim državam. S podobno negotovostjo glede prihodnjih nalog se srečujejo tudi v Natu. Zavezništvo poleg odvračanja in obrambe, ki še vedno spadata med njegove temeljne naloge, po hladni vojni izvaja vrsto vojaških nalog, ki niso povezane s kolektivno obrambo. ${ }^{13}$

V svetovnem merilu je velika verjetnost dinamičnih in nepredvidljivih dogajanj $\mathrm{v}$ prihodnosti in tudi verjetnost varnostnih groženj in konfliktov. Vsako predvidevanje o uporabi vojaške sile je pravzaprav zelo tvegano. ${ }^{14} \mathrm{Z}$ vidika osredotočenosti na evropski kontekst pa je mogoče orisati nekatere dejavnike, ki bodo vsaj na splošno opredeljevali vlogo vojaškega dejavnika. Gre za povezanost evropskega prostora, varnostna ureditev v tem prostoru pa je tudi močno institucionalizirana. Ključne varnostne probleme bo $\mathrm{v}$ prihodnje Evropa verjetno reševala predvsem $\mathrm{v}$ okviru EU in Nata. Tudi uporaba vojaške sile bo v prihodnje najbrž večinoma potekala na multilateralnih temeljih v okviru EU ali Nata.

V evropskih okvirih je pomembna norma uporabe vojaške sile multilateralizem. ${ }^{15}$ Kot ugotavlja Forster (2006: 264-7), se je multilateralizem uveljavil kot značilnost evropske varnostne ureditve, posebej skozi izvajanje misij, ki so postale posebej številčne v devetdesetih letih. Nato in EU sta odigrala ključno vlogo pri uveljavljanju te prakse. Multilateralizem je dejansko osnovni gradnik obeh organizacij. EU je v svoji Varnostni strategiji kot enega od ciljev postavila »učinkovit multilateralizem« (Evropska varnostna strategija, 2003), koncept delovanja Nata pa temelji na kolektivni obrambi (5. člen SAP), posvetovanju (4. člen SAP) in vedno bolj tudi kolektivni varnosti, ki je bila v strateškem konceptu Nata iz leta 2010 tudi razglašena za eno od nalog Nata.

Integriranost in praksa multilateralnosti v evropskem prostoru sestavljata specifični varnostni kontekst, v katerem se oblikujejo skupne identitete in politike, usmerjene

\footnotetext{
${ }^{13}$ Pogosto te naloge označujejo s skupnim imenom »operacije izven 5. člena SAP (non-Article 5 operations). Za podrobnejši opis Natovih vojaških in drugih nalog glej Yost, 2010, posebej str. 490-4.

${ }_{14}$ V bližnji preteklosti je prišlo do vrste oboroženih konfliktov ali vojn, ki so izbruhnile nepričakovano in so pomenile presenečenje. Kot primere lahko navedemo iraško okupacijo Kuvajta in Zalivsko vojno leta 1991, ki je temu sledila; t. i. arabsko pomlad, ko so nemiri zajeli večje število držav v Severni Afriki in na Bližnjem vzhodu ter posredovanje Rusije na ukrajinskem polotoku Krim leta 2014.

${ }_{15}$ Danes $v$ svetovnih merilih najdemo soobstoj dveh načel pri vzdrževanju mednarodnega reda. Prvo je uveljavljanje multilateralizma, ki pomeni, da mora vzdrževanje reda potekati na način, o katerem se sporazumejo vse države, ki so glavni delovalci v mednarodnem sistemu, in da mora delovanje potekati z odobritvijo mednarodne skupnosti, zastopane prek OZN. Drugi pristop favorizira delovanje po lastni presoji, če je treba tudi brez mednarodnega soglasja. Izvajajo ga predvsem ZDA kot edina preostala velesila (Gray, 2012, str. 339-40).
} 
v prihodnost. Zato so lahko pogledi in ocene, ki obravnavajo prihodnjo varnostno okolje in vlogo Nata in EU, razmeroma dober indikator prihodnje vloge vojsk njunih članic. V nadaljevanju je predstavljeno nekaj analiz, ki obravnavajo verjetno prihodnost, so kot »kažipot« politiki in v najširšem smislu začrtujejo okvire o vlogi vojaške sile v prihodnje.

Leta 2013 sta Natovi strateški poveljstvi za operacije in transformacijo pripravili poročilo Strategic Foresight Analysis, ki predstavlja poglede na prihodnje strateško okolje zavezništva. Poročilo ugotavlja, da prihodnost ni povsem predvidljiva niti vnaprej opredeljena, vedno pa obstaja možnost »strateških šokov«. Politično bo prihodnost opredeljeval pojav novih velesil, kar bo lahko vir nestabilnosti, na Nato pa bodo lahko vplivale krize, oddaljene od njegovega območja. Družbene spremembe bodo posegale na področje demografije in pospeševale procese urbanizacije, vplivale na omrežja ljudi ter krhanje njihovih identitet. Kot posledica urbanizacije se lahko pojavi potreba po izvajanju bojnih ali varnostnih operacij v urbanih okoljih. Nadaljeval se bo hiter razvoj na znanstvenem področju in potencialni nasprotniki bodo imeli povečane možnosti dostopa do inovativnih tehnologij. Mednarodni tokovi dobrin, ljudi, informacij, denarja in idej bodo v globaliziranem svetu ključni, njihovo morebitno pretrganje pa bi imelo daljnosežne posledice. Globalne posledice bo imelo tekmovanje za redke surovine, hrano, vodo in energetske vire (Strategic Foresight Analysis, 2013).

Razmišljanja v zavezništvu o prihodnjih varnostnih grožnjah in vlogi vojske je mogoče predstaviti na podlagi dveh analiz, nastalih v zadnjih letih. Leta 2010 je bila objavljena analiza NATO 2020: Assured Security; Dynamic Engagement, ki je nastala $\mathrm{v}$ procesu priprav novega strateškega koncepta Nata, sprejetega istega leta na vrhunskem srečanju v Lizboni. Analiza opozarja na spremembe temeljnih funkcij Nata: zavezništvo v hladni vojni je bilo usmerjeno predvsem na koncentriranje vojaških sil za odvračanje ali odbijanje napada na ozemlje članic. V sodobnosti skrb zavezništva vzbujajo dogajanja $\mathrm{v}$ njegovem okolju, kot na primer možnost, da bi regionalni spori ali poskusi političnega izsiljevanja spodkopali varnost vzdolž njegovih meja, pa tudi spremenljive in manj predvidljive nevarnosti, kot so terorizem, širitev jedrskih in drugih naprednih oborožitvenih tehnologij, kibernetski napadi, sabotaže na energetskih cevovodih in prekinitev kritičnih pomorskih oskrbovalnih poti. Učinkovito zoperstavljanje tem grožnjam se mora pogosto začeti daleč prek meja članic zavezništva. Možnosti neposrednega napada na zavezništvo so v doglednem času majhne (NATO 2020, 2010, str. 3-5). Nato in EU ostajata osrednje območje stabilnosti v evroatlantskem prostoru in čeprav je na tem območju vrsta problemov, je verjetnost vojaških konfliktov (meddržavnih ali notranjih) zelo majhna (prav tam, str. 12).

V prihodnje bodo, kot navaja analiza varnostno pomembne teme »odnosi z Rusijo«, dogajanja v srednji Aziji, na Bližnjem vzhodu, v Azijsko-pacifiški regiji in Afriki. Vendar pa iz nobenega od teh sklopov problemov ne izvirajo ozemeljske grožnje območju zavezništva. Oceno varnostnega okolja v poročilu zaključuje ugotovitev, 
da konvencionalna vojaška agresija na zavezništvo ali njegove članice ni verjetna, vendar takšne možnosti ne moremo povsem izključiti. Najbolj verjetne grožnje zaveznicam v prihajajočem desetletju so nekonvencionalne in predvsem:

1. napad $\mathrm{z}$ balističnim raketami,

2. napadi mednarodnih terorističnih skupin,

3. različno obsežni kibernetski napadi (prav tam, str. 14).

Istega leta so strokovnjaki nacionalne obrambne univerze ZDA objavili poročilo Affordable Defense Capabilities for Future NATO Missions. Poročilo obravnava bodoče naloge Nata in potrebne reforme oziroma pobude za učinkovito izvajanje nalog. V novih razmerah, ugotavlja poročilo, bo Nato potreboval zmogljivosti za operativno delovanje daleč prek svojih teritorialnih meja, posebno v pomorskem prostoru, vesolju in kibernetskem prostoru. Delovanje Nata bo obsegalo zelo različne aktivnosti oziroma odzive na grožnje, saj »varnosti ni mogoče definirati več samo v smislu obrambe ozemlja« (Affordable Defense Capabilities, 2010, str. 7). Prihodnje naloge Nata so razdeljene v štiri ključne kategorije: 1. zagotavljanje kolektivne obrambe na temelju 5. člena SAP, ki obsega konvencionalno, strateškojedrsko in pomorsko dimenzijo; 2. spopadanje z netradicionalnimi grožnjami državi in družbi, ${ }^{16}$ predvsem s terorizmom, nevarnostjo uporabe orožij za množično uničevanje in kibernetskimi napadi; 3. ekspedicijsko delovanje v odzivanju na krize in zagotavljanje stabilnosti v postkonfliktnem obdobju, ki poleg razvoja sodobnih vojaških zmogljivosti za ekspedicijsko delovanje zahteva tudi dopolnjevanje $\mathrm{z}$ različnimi civilnimi aktivnostmi - tako imenovani celovit pristop (comprehensive approach); 4. obrambna diplomacija, ki obsega sodelovanje z nečlanicami na področju vojaškega usposabljanja, reform in oblikovanja interoperabilnosti z Natom (podrobneje v tabeli 1).

Tudi v povezavi z vlogo EU lahko najdemo podobna pričakovanja o nalogi vojske $\mathrm{v}$ prihodnje. Proces razvoja koncepta in strukture skupne varnostne in obrambne politike spremljajo analize varnostnega okolja in različnih scenarijev uporabe vojaške sile v prihodnje. Njihov namen je podpora prizadevanjem za razvoj ustreznih vojaških zmogljivosti članic. Leta 2006 je nastala študija Long Term Vision, ki na podlagi predvidevanj dogajanj do leta 2025 predstavlja te ključne spremembe glede oboroženih sil:

1. vlogo vojaških sil bo zaznamoval prehod od vojskovanja industrijske dobe $\mathrm{k}$ vojskovanju informacijske dobe;

2. stopnjevanje tempa tehnoloških sprememb;

3. ekspedicijsko, koalicijsko in celovito (comprehensive) vojskovanje, ki bo bolj kot $\mathrm{k} »$ zmagi« usmerjeno $\mathrm{v}$ doseganje stabilnosti.

\footnotetext{
${ }^{16}$ Po letu 2001 v ZDA in tudi v Natu in nekaterih članicah tovrsten vidik varnosti označujejo z izrazom »omovinska varnost« (homeland security).
} 
Tabela 1:

Kategorije nalog

in pobude $v$

okviru Nata

Povzeto po:

Affordable

Defense

Capabilities,

2010.

\begin{tabular}{|c|c|}
\hline Naloge & Pobude za zmogljivosti \\
\hline \multirow{3}{*}{$\begin{array}{l}\text { Zagotavljanje varnosti } \\
\text { v povezavi s } 5 \text {. členom } \\
\text { SAP - odvračanje in } \\
\text { obramba }\end{array}$} & $\begin{array}{l}\text { Pobude na področju konvencionalnih zagotovil: dograjevanje sistema kriznega } \\
\text { menedžmenta, zmogljivosti strateškega ocenjevanja, sistema načrtovanja in } \\
\text { vaj; reorganizacija in dograjevanje Večnacionalnega korpusa Severovzhod } \\
\text { in Natovih odzivnih sil; vzdrževanje operacije varovanja zračnega prostora } \\
\text { baltskih držav in koordinirana vojaška pomoč tem državam. }\end{array}$ \\
\hline & $\begin{array}{l}\text { Pobude na področju strateških zagotovil: vzdrževanje kredibilnega sistema } \\
\text { jedrskega odvračanja; razvoj režima odvračanja od uporabe jedrskega orožja } \\
\text { proti zaveznicam (vključno s protiraketno obrambo); nadaljnji razvoj in } \\
\text { integracija sistema balistične raketne obrambe; zagotovitev dostopnosti do } \\
\text { vesoljskega prostora. }\end{array}$ \\
\hline & $\begin{array}{l}\text { Pobude glede sposobnosti poznavanja spremljanja pomorske situacije: } \\
\text { krepitev možnosti poznavanja situacije na periferiji Nata (skrajni sever, Perzijski } \\
\text { zaliv, Indijski ocean); integracija pomorskih operacij Nata in EU; krepitev } \\
\text { skupne pomorske obveščevalne mreže. }\end{array}$ \\
\hline \multirow{3}{*}{$\begin{array}{l}\text { Preprečevanje in } \\
\text { odpravljanje posledic } \\
\text { netradicionalnih groženj } \\
\text { varnosti članic }\end{array}$} & $\begin{array}{l}\text { Pobude na področju delovanja proti terorizmu: širitev veljavnih programov in } \\
\text { obveščevalnih aktivnosti na tem področju. }\end{array}$ \\
\hline & $\begin{array}{l}\text { Pobude za obvladovanje posledic morebitne uporabe orožij za množično } \\
\text { uničevanje in množičnih nesreč. }\end{array}$ \\
\hline & $\begin{array}{l}\text { Pobude za zagotavljanja kibernetske obrambe: zaščita lastnih omrežij, razvoj } \\
\text { zmogljivosti zgodnjega opozarjanja, razvoj usposabljanja ter vaj za kibernetsko } \\
\text { obrambo. }\end{array}$ \\
\hline \multirow{4}{*}{$\begin{array}{l}\text { Izvajanje ekspedicijskih } \\
\text { operacij kriznega } \\
\text { odzivanja in } \\
\text { stabilizacijskih operacij }\end{array}$} & $\begin{array}{l}\text { Pobude za krepitev premestljivosti in uporabnosti Natovih sil v visoki } \\
\text { pripravljenosti; izboljšave procesa načrtovanja in generiranja sil; razvoj doktrine } \\
\text { in standardov ter izobraževanja in urjenja za večnacionalno delovanje. }\end{array}$ \\
\hline & $\begin{array}{l}\text { Pobude za interoperabilnost na področju C4ISR*: nadaljnji razvoj tehnologij, } \\
\text { ki jih omogoča omrežje in razvoj sposobnosti povezovanja nacionalnih } \\
\text { elementov v strateško-operativna omrežja. }\end{array}$ \\
\hline & $\begin{array}{l}\text { Pobude za nadaljnji razvoj celostnega (vojaškega in civilnega) pristopa: razvoj } \\
\text { znanja in vzpostavitev centra odličnosti za to področje; izboljšanje vključevanja } \\
\text { civilnih zmogljivosti v izvajanje stabilizacijskih operacij. }\end{array}$ \\
\hline & Pobude za povečanje interoperabilnosti sil za specialno delovanje. \\
\hline \multirow{3}{*}{ Obrambna diplomacija } & $\begin{array}{l}\text { Pobude za interoperabilnost z državami nečlanicami: zagotavljanje pomoči pri } \\
\text { reformah oboroženih sil; ugotavljanje »nišnih« zmogljivosti. }\end{array}$ \\
\hline & $\begin{array}{l}\text { Pobude na področju vojaškega urjenja in obrambnih reform ter vojaške } \\
\text { pomoči nečlanicam/partnerjem. }\end{array}$ \\
\hline & $\begin{array}{l}\text { Vojaško sodelovanje z nečlanicami/nekdanjimi nasprotnicami (Rusija, Srbija, } \\
\text { Kitajska). }\end{array}$ \\
\hline
\end{tabular}

* - command, control, communications, computers, intelligence, surveillance and reconnaissance

Leta 2013 je bila končana študija Inštituta EU za varnostne študije Enabling the Future, ki obravnava mogoče prihodnje scenarije varnostnega okolja in vrste vojaških operacij v okviru EU ter daje predloge za nadaljnjo krepitev vojaških zmogljivosti EU. Izhaja iz analize varnostnega okolja in groženj do leta 2025. Prihodnje grožnje varnosti so predvsem v nerešenih vprašanjih vzhodne in južne soseščine EU, to so nestabilnosti, do katerih je v zadnjih nekaj letih pripeljala tako imenovana arabska 
pomlad, pa tudi nestabilnosti v celotnem loku, ki se razteza od zahodne do vzhodne Afrike, do Perzijskega zaliva, Indijskega oceana in v osrednjo Azijo (Enabling the Future, 2013, str. 16 in 20). Kljub priznavanju, da je oblikovanje scenarijev glede prihodnosti zelo tvegano, so avtorji oblikovali šest ilustrativnih scenarijev prihodnjih varnostnih groženj:

1. grožnje varnosti članicam EU (Threats to the European Homeland): grožnjo bi v tem primeru predstavljala avtoritarna etnonacionalistična država na obrobju EU, ki bi lahko posegla po klasičnih vojaških grožnjah in predvsem po kibernetskih napadih. Ni pričakovati resnejšega ogrožanja ozemlja EU, odgovor na grožnjo pa bi obsegal predvsem odvračanje napada z zagotavljanjem ustrezne obrambe ozemlja in obrambo pred kibernetskimi napadi;

2. kritična nestabilnost $\mathrm{v}$ jugovzhodni Aziji: pojav in ambicije nove velesile v tem območju bi znatno omajala stabilnost. Nestabilnost bi v veliki in predvsem pomorski regiji glede na njene interese zahtevala prisotnost pomorskih sil EU v regiji;

3. boj za moč v indijsko-pacifiškem območju: morebitne napetosti in ustvarjanje koalicij okoli večjih držav tega območja bi lahko pripeljale do spopadov, ki bi ogrozili plovbo v Arabskem morju in Hormuški ožini. To bi zahtevalo angažiranje pomorskih sil držav EU za ohranjanje odprtih pomorskih poti v tej regiji;

4. humanitarna kriza v osrednji Afriki: nastanek nemirov in uporabe oboroženega nasilja po zlomu državnih struktur v enih izmed držav tega območja. Posledično pride do humanitarne krize in žrtev ter do nujnosti evakuacije evropskih državljanov iz države. Položaj zahteva humanitarno posredovanje članic EU in vzpostavitev območja prepovedi letenja ter zračne napade za preprečevanje agresivnega delovanja režima, ob globljem zapletanju v krizo pa tudi posredovanje kopenskih enot;

5. grožnje kritični infrastrukturi v svetu: ekstremna skupina $\mathrm{v}$ eni izmed držav v regiji osvoji oblast, zasede območja okoli Sueškega prekopa ter ob grožnji z orožjem zahteva posebne »dajatve« za prehod ladij. Za zagotovitev svobodne plovbe je treba uporabiti zračne in letalske sile;

6. agresivno vedenje režima na Bližnjem vzhodu; ena izmed držav v regiji vodi vse bolj agresivno mednarodno politiko, razvije jedrske zmogljivosti, s katerimi lahko ogrozi ozemlje Evrope in izvede poseg proti manjši, prozahodno usmerjeni sosedi. Položaj zahteva mednarodno posredovanje, od članic EU se pričakuje, da bodo zagotovile dovolj sil za obsežno ekspedicijsko posredovanje, vključno s pomorskimi in zračnimi silami, treba je zagotoviti tudi taktično in strateško protiraketno obrambo.

Avtorji študije menijo, da obsežnejša konvencionalna vojaška grožnja ozemlju članic EU v bližnji prihodnosti ni verjetna. Najbolj verjetne so grožnje kibernetskega napada in balističnega raketnega napada, kar pa zahteva posebno vrsto odziva. Kot najbolj verjetne vrste vojaških operacij pod okriljem EU obravnavajo delovanje zunaj območja Evrope, in sicer s prisotnostjo vojaških sil ter ofenzivnimi in defenzivnimi delovanji - tabela 2. Vojske evropskih držav se pri tem srečujejo z novo paradigmo vojaških operacij, ki jo zaznamuje na omrežje osredotočeno (net-centric) koalicijsko 
in ekspedicijsko vojskovanje (Enabling the Future, 2013, str. 9). Poleg navedenih aktivnosti je pričakovati tudi potrebo po angažiranju pri izvajanju mirovnih operacij in stabilizacijskih aktivnostih na območjih konfliktov.

\begin{tabular}{|c|c|c|}
\hline \multirow{6}{*}{$\begin{array}{r}\text { Tabela 2: } \\
\text { Mogoče vrste } \\
\text { vojaških operacij } \\
\text { pod okriljem EU } \\
\text { do } 2025 \\
\text { Vir: } \\
\text { Enabling the } \\
\text { Future, } 2013 \\
\text { str. } 28 .\end{array}$} & \multirow{2}{*}{$\begin{array}{l}\text { Prisotnost sil v soseščini EU } \\
\text { (forward presence) }\end{array}$} & $\begin{array}{l}\text { Pomorske patrulje za krepitev regionalnega zaupanja, zaščito tržnih } \\
\text { komunikacij ali preprečevanje piratstva (npr. v Indijsko-pacifiški regiji ali } \\
\text { Gvinejskem zalivu) }\end{array}$ \\
\hline & & $\begin{array}{l}\text { Obvladovanje pomorskega območja za odvračanje agresije v obdobjih } \\
\text { napetosti }\end{array}$ \\
\hline & \multirow{2}{*}{$\begin{array}{l}\text { Ofenzivne naloge } \\
\text { (offensive missions) }\end{array}$} & Napotitev sil za ustavitev državljanske vojne v Srednji Afriki ali kje drugje \\
\hline & & $\begin{array}{l}\text { Ekspedicijsko vojskovanje za omejevanje agresivnega režima na območju } \\
\text { širšega srednjega vzhoda }\end{array}$ \\
\hline & \multirow{2}{*}{$\begin{array}{l}\text { Defenzivne naloge } \\
\text { (defensive missions) }\end{array}$} & $\begin{array}{l}\text { Obramba (po možnosti odvračanje) kibernetskih ali balističnih raketnih } \\
\text { napadov na ozemlje evropskih držav }\end{array}$ \\
\hline & & $\begin{array}{l}\text { Zaščite čezmorskih ozemelj ali kritične infrastrukture (npr. Sueškega } \\
\text { prekopa) }\end{array}$ \\
\hline
\end{tabular}

Prikazane analize in ilustrativni scenariji morebitnih prihodnjih varnostnih groženj Natu ali EU kažejo tudi na pričakovanja glede najverjetnejše vloge vojske $\mathrm{v}$ prihodnosti. Njena vloga je tudi odraz specifičnega položaja in interesov Evrope. Pri reševanju notranjih problemov evropskega območja, to je med članicami EU in Nata, vojaška sila zelo verjetno ne bo imela nobene vloge. Glede morebitne uporabe vojaške sile bodo večjega pomena turbulentni dogodki v soseščini Evrope in na globalni ravni. Uporaba vojaške sile ostaja eden izmed instrumentov politike zaradi morebitnega vpliva nestabilnosti v soseščini, energetske odvisnosti, pomembnosti transportnih poti, ki Evropo povezujejo s svetom, in drugih dejavnikov, zaradi katerih je Evropa občutljiva za dogajanja v svojem okolju. Vzrok za uporabo vojaške sile je lahko tudi humanitarno posredovanje.

Kot najverjetnejše neposredne grožnje, ki bi imele posledice tudi na ozemlju napadene države, so obravnavani kibernetski napadi, raketni napadi in uporaba orožij za množično uničevanje ter teroristični napadi. Teroristično delovanje bi najverjetneje potekalo v urbanem okolju. Vse to pa so grožnje, proti katerim klasični koncepti obrambe ozemlja niso učinkoviti. V članicah Nata in EU najverjetneje ne bo prihajalo do obrambe lastnih meja oziroma vojaško delovanje ne bo potekalo na njihovem ozemlju. Veliko bolj verjetno pa je ekspedicijsko vojaško delovanje z visoko tehnološko razvitimi silami, ki pa se bo razlikovalo od meddržavnih vojn $\mathrm{v}$ preteklosti. 
Sklep V evropskih državah se zaradi sprememb v zadnjih dveh desetletjih vloga vojsk pomembno spreminja. Pomen pridobivajo funkcije, ki niso tipično vojaške, kot sta vojaška diplomacija in pomoč domačim oblastem, vendar temeljni namen vzdrževanje vojsk ostaja varovanje pred grožnjami, ki izvirajo iz mednarodnega okolja držav. Izrazito se je zmanjšal pomen vojske za obrambo ozemlja, kar je bila v preteklosti njena prednostna naloga. Vse to zahteva drugačne pristope k razumevanju in organiziranju vojsk. Te ostajajo eden izmed instrumentov zagotavljanja nacionalne varnosti, vendar se poudarek v njihovi uporabi preusmerja k spopadanju z grožnjami, ki ne ogrožajo ozemeljske celovitosti države. Prevladujoča logika multilateralnega pristopa $\mathrm{k}$ varnostnim problemom in večnacionalne uporabe vojske pa pomeni, da je vojsko vse težje razumeti le v povezavi s funkcijo obrambe države, temveč je o njeni vlogi treba razmišljati v kontekstu varnosti, ki pa je v globaliziranem svetu veliko bolj celovita kategorija.

Zelo verjetno bodo $\mathrm{v}$ prihodnosti nastajali konflikti, ki bodo od evropskih držav zahtevali tudi vojaške ukrepe. Pri tem je malo verjetno, da bi prišlo do potrebe po obrambi lastnega ozemlja, temveč bodo vojske opravljale druge naloge, predvsem z različnimi posredovanji zunaj območja lastne države. Proces preoblikovanja obrambnih doktrin in strukture vojsk, ki to preobrazbo spremlja, ni preprost. Glede tega so med evropskimi državami tudi precejšnje razlike. ${ }^{17}$ Ker bodo krizne razmere lahko zahtevale posredovanje, ki ne bo neposredno povezano z obrambo ozemlja države, se v novi luči odpirajo vprašanja uporabe vojsk. Vprašanja legitimnosti in legalnosti uporabe vojaške sile bodo verjetno precej bolj zapletena kot v primeru tradicionalnih meddržavnih spopadov. V posameznih primerih vojaških posegov, še posebej večnacionalnih, je lahko povezava med neposrednimi nacionalnovarnostnimi interesi države in uporabo vojaške sile manj jasna in neposredna. Pričakovati je tudi, da se bodo zaostrila vprašanja o upravičenosti uporabe vojaške sile z vidika učinkovitosti doseganja zastavljenih ciljev. Tako so na primer do posegov v Iraku in Afganistanu danes številne evropske države precej skeptične. Podobna stališča lahko zasledimo tudi glede sicer vojaško uspešnega Natovega posredovanja v Libiji.

Danes enega izmed strateških dejavnikov predstavljajo tudi stališča javnosti do uporabe vojaške sile in skladno s tem se odpirajo tudi vprašanja, kako izvajanje različnih nalog vpliva na položaj vojske v družbi. Izrazit problem, povezan s spremembo vloge vojske, je tudi razvoj ustreznih vojaških zmogljivosti. Posredovanje v različnih kriznih situacijah, obramba pred balističnimi raketnimi in kibernetskimi napadi ipd. zahteva bistveno drugačne in bolj raznovrstne zmogljivosti kot obramba ozemlja države. Tudi na tem področju se evropske države z različnim tempom prilagajajo novim zahtevam, prevladujoč splošen problem pa je neustreznost za obrambo ozemlja prilagojenih vojaških sil za nove naloge.

\footnotetext{
${ }_{17}$ Te se na primer kažejo v Natu kot razlike med pripravljenostjo in sposobnostjo posameznih zaveznic za prispevek $k$ operacijam zavezništva in strukturi Natovih odzivnih sil. Po eni izmed ocen je v EU samo tretjina držav članic takšnih, za katere lahko rečemo, da obrambne zadeve obravnavajo resno in ki so prepričane, da je s posredovanjem mogoče reševati varnostne probleme (Grant v Yost, 2010, str. 521).
} 
Za oblikovalce obrambne politike je razumevanje varnostnega okolja in bodoče vloge vojske ključnega pomena. Spreminjanje vloge vojske v sodobnih varnostnih razmerah predstavlja številne izzive. Ti so po eni strani povezani z odnosom med vojsko in njenim družbenim okoljem, kot na primer javna podoba in sprejemljivost vojske, zaupanje javnosti, legitimnost uporabe vojaške sile idr. Po drugi strani pa se vojske srečujejo z izzivi glede ustrezne notranje reorganizacije, strukture, tehnološke opremljenosti, izurjenosti idr., kar mora zagotoviti njihovo učinkovitost pri izvajanju pričakovanih nalog. Razumevanje vojske kot enega izmed varnostnih instrumentov države, katerega naloge $\mathrm{v}$ sodobnosti presegajo obrambo ozemlja države pred zunanjim vojaškim ogrožanjem, lahko znatno pripomore $\mathrm{k}$ reševanju vprašanj o njenem položaju v družbi in njenem strukturnem preoblikovanju.

1. Affordable Defense Capabilities for Future NATO Missions. 2010. Washington. National Defence University.

2. Arnold, M., J., 2008. Intervention. V Snyder C., A., ur. Contemporary Security and Strategy. New York: Palgrave Macmillan.

3. Asmus, R., et al. 2010. NATO, new allies and reassurance. Centre for European Reform. www.cer.org.uk/publications/archive/policy-brief/2010/nato-new-allies-and-reassurance, 3. 12. 2013.

4. Art, J. R., 1992. The Four Functions of Force. V Art J. R. in Jervis R.: International Politics: Enduring Concepts and Contemporary Issues. New York. Harper Collins Publishers.

5. Bebler, A., 2006. EU, Nato in sodobni mednarodni terorizem. V Malešič, M., (ur.) Varnost v postmoderni družbi. Ljubljana. Fakulteta za družbene vede.

6. Cottey, A., Forster, A., 2004. Reshaping Defence Diplomacy: New Roles for Military Cooperation and Assistance. Adelphi Paper 365. London, Oxford University Press.

7. Enabling the Future. European military capabilities 2013-2025: challenges and avenues. 2013. EU Institute for Security Studies. http://www.iss.europa.eu/publications/detail/ articlelenabling-the-future-european-military-capabilities-2013-2025-challenges-andavenues/, 26. 11. 2013

8. Edmunds, T., 2005. A New Security Environment? The Evolution of Military Roles in Post-Cold War Europe. V Edmunds, T., Malešič, M., ur. Defence Transformation in Europe: Evolving Military Roles. Amsterdam, Berlin. IOS Press.

9. Fabjan, A., 2012. Analiza Strateškega koncepta Nata 2010. Sodobni vojaški izzivi, 14-4.

10. Flockhart, T., 2011. After the Strategic Concept: Towards a Nato Version 3.0. Copenhagen, Danish Institute for International Studies.

11. Forster, A., 2006. Armed Forces and Society in Europe. London. Palgrave MacMillan.

12. Garnett, J., 1987. The Role of Military Power. V Baylis, J. et al. Contemporary Strategy: Theories and Concepts. New York, London. Holmes \& Meier.

13. Geigerich, B., Nicoll, A., 2012. The Struggle for Value in European Defence. SurvivalGlobal Politics and Strategy, 54/1.

14. Global Trends 2025: A transformed World. 2008. http://www.dni.gov/index.php/ newsroom/reports-and-publications?start=35 , 5. 12. 2012.

15. Gray, S., C., 2012. War, Peace and International Relations: An introduction to Strategic History. London, New York. Routledge.

16. Grizold, A., Bučar, B., 2011. Izzivi sodobne varnosti: od nacionalne in mednarodne varnosti do človekove varnosti. Teorija in praksa, 48-4.

17. Kaldor, M., 2006. New \& Old Wars. Cambridge. Polity Press. 
18. Keohane, R., Nye, J., 1989. Power and Interdependence. Harper Collins Publishers.

19. King, A., 2010. The Internationalization of the Armed Forces. V Soeters, J., C. van Fenema, P., Beeres, R. Managing Military Organizations: Theory and practise. London, New York. Routledge.

20. Kotnik, I., 2012. Orchestrating the Instruments of National Power. Sodobni vojaški izzivi, $14-3$.

21. Long Term Vision for European Defence Capability and Capacity Needs. 2006. European Defence Agency. http://www.eda.europa.eu/docs/documents/Long-Term_Vision_Report, 3. 1. 2014.

22. Malešič, M., 2005. Introduction: the Challenge of Defence Transformation in Europe. $V$ Edmunds, T., Malešič, M. ur. Defence Transformation in Europe: Evolving Military Roles. Amsterdam, Berlin. IOS Press.

23. Moskos, C., Williams, J., A., Segal, D., R., 2000. The Postmodern Military. New York, Oxford. Oxford University Press.

24. Moskos, C., 2005. Military Systems in the $21^{\text {st }}$ Century: Changes and Continuities. V Edmunds, T., Malešič, M. ur. Defence Transformation in Europe: Evolving Military Roles. Amsterdam, Berlin. IOS Press.

25. NATO 2020: Assured Security; Dynamic Engagement. 2010. http://www.nato.int/nato static/assets/pdf/pdf_2010_05/20100517_100517_expertsreport.pdf, 20. 12. 2013.

26. Osinga, F., Lindley-French, J., 2010. Leading Military Organizations in the Risk Society: Mapping the New Strategic Complexity. V Soeters, J., C. van Fenema, P., Beeres, R. ur. Managing Military Organizations: Theory and practise. London, New York. Routledge.

27. Soeters, J., Fenema, P., C., Beeres, R., 2010. Introducing Military Organization. V Soeters, J., C. van Fenema, P., Beeres, R. ur. Managing Military Organizations: Theory and practise. London, New York. Routledge.

28. Strategic Monitor, 2012. Netherlands Institute of International Relations 'Clingendael'. Hague.

29. Strategic Foresight Analysis. NATO, 2013. http://www.act.nato.int/sfa-report , 6. 10. 2013.

30. Svete, U., Guštin, D., Prebilič, V., 2010. Asimetrija in vojaška organiziranost: slovenske izkušnje. VMalešič, M., (ur.) Mednarodne razsežnosti varnosti Slovenije. Ljubljana, Fakulteta za družbene vede.

31. Yost, S., D., 2010. NATO's Evolving Purposes and the Next Strategic Concept. International Affairs, 86-2.

32. Watanabe, L., 2010. Securing Europe. Palgrave Macmillan.

33. Zapolskis, M., 2010. Redefining the EuroAtlantic Security Agenda: What is the Role for the New NATO Strategic Concept? Lithuanian Foreign Policy Review, 23/2010.

34. Žabkar, A., 2005. Izzivi tretjega tisočletja in oborožene sile. V Beber A., (ur.) Sodobno vojaštvo in družba. Ljubljana, Fakulteta za družbene vede. 